IMPACT OF PATIENT SAFETY CULTURE ON MEDICAL ERROR ATTITUDES: AN APPLICATION IN NURSES

\title{
Hasta Güvenliği Kültürünün Tıbbi Hata Tutumları Üzerine Etkisi: Hemşirelerde Bir
}

\section{Uygulama}

\author{
Gülcan ŞANTAŞ ${ }^{1}$ (1) Özlem ÖZER ${ }^{2}$ (1) \\ Mehmet Bircan GÜLEÇ \\ ${ }^{1,3}$ Yozgat Bozok Üniversitesi, İktisadi ve İdari Bilimler Fakültesi, Yozgat \\ ${ }^{2}$ Sağlık Bilimleri Üniversitesi, Gülhane Să̆lık Bilimleri Fakültesi, Ankara \\ ${ }^{4}$ Akdeniz Üniversitesi Hastanesi, Antalya
}

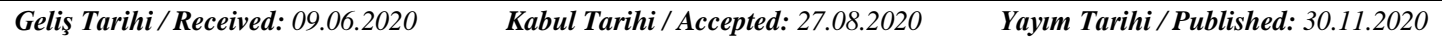

Keywords: Medical Error, Nurse, Patient Safety Culture

\section{ÖZ}

$\mathrm{Bu}$ çalışma, hemşirelerin hasta güvenliği kültürü algılarının tıbbi hatalara yönelik tutumlarına etkisini incelemeyi amaçlamaktadır. Çalışmanın evrenini Antalya'da bir devlet hastanesinde çalışan hemşireler oluşturmaktadır $(n=350)$. Çalışmada kolayda örnekleme yöntemi kullanıldı ve 205 hemşireden anket toplandı. Veriler, 2 Ekim-3 Kasım 2018 tarihleri arasında elde edildi. Çalışma sonuçları, hasta güvenliği kültürü boyutlarının tıbbi hata algısı üzerindeki toplam varyansın \%28.2'sini, tıbbi hata yaklaşımı üzerindeki toplam varyansın 26.4\%'ünü, tıbbi hata nedenleri üzerindeki toplam varyansın \%21.8'ini açıkladığını göstermektedir. Ayrıca hasta güvenliği kültürü, tıbbi hatanın tüm alt boyutları üzerindeki toplam varyansın \%32'sini açıklamaktadır. Bu çalışmanın sonuçları, hastaları sağlık kurumlarındaki tıbbi hatalardan korumak için hasta güvenliği kültürünün geliştirilmesinin önemini vurgulamaktadır. Bu çalışma aynı zamanda hasta güvenliği kültürünün başarılı bir şekilde uygulanması için dikkate alınması gereken faktörleri de ortaya koymuştur. Tıbbi hataları azaltma ve hasta güvenliği kültürünü geliştirme konusunda ortak bir anlayışa sahip olunması ve farkındalığın artırılması önerilmektedir.

Anahtar kelimeler: Hasta Güvenliği Kültürü, Hemşire, Tıbbi Hata 


\section{INTRODUCTION}

Patient safety is an important mainstay of health care quality (Aboneh, Stone, Lester \& Chui, 2020). Patient safety culture is defined as a component of organizational culture with regard to the values, attitudes, perceptions and faiths of health employees. Therefore, it involves the collective assessment of the attitudes and beliefs of all personnel within the organization (Iramaneerat \& Noppakunsomboon, 2016). Patient safety culture consists of the beliefs shared among organization members, the mutual effect of work units and the structures and systems of the organization (Singer, Lin, Falwell, Gaba \& Baker, 2009). It is the sum of the outputs of the values, attitudes, perceptions, authority, behaviors and skills of safety management in organization (Nieva \& Sorra, 2003). The topic concerns health institutions because of the relevance of patient-adverse events (Tschudi Bondevik et al., 2017).

Patient safety culture in health institutions has three key elements. Healthcare processes can be designed in the light of these elements: a) identifying mistakes and deriving lessons from the mistakes; b) the presence of responsibility at organizational level and an atmosphere that equilibrates the requirement of reporting events; c) the requirement of performing disciplinal actions with others (Handler et al., 2006; Institute of Medicine, 2004). Safety culture includes seven sub-cultures of patient safety culture. These sub-cultures are leadership, group working, evidence-based care, dialogue, training, fairness and patient centered care (Sammer, Lykens, Singh, Mains \& Lackan, 2010). A positive safety culture is identified with effective teamwork, communication, nonpunitive response to errors, and collaborative learning (Wagner, Brush, Castle, Engberg \& Capezuti, 2017).

Patient safety culture is used for the assessment of safety culture by health institutions, identification of fields for patient safety improvement, evaluation of patient safety attempts, and meeting and complying with legislative necessities (Elsous et al., 2016). Thus, health institutions may acquire a clear view of patient safety aspects requiring immediate notice, describe the strengths, weaknesses and existing safety matter, and benchmark their points with other health institutions (Stavrianopoulos, 2012).

Medical error is a very comprehensive issue in recent years. It has been discussed over ethnical, legal, medical, educational and administrative aspects (Dikmen, Yorgun \& Yeşilçam, 2014). Medical error is defined as the failure to complete medical intervention as intended during the provision of health services (Karataş \& Yakınc1, 2010). Reporting medical errors is critical to advance the safety systems through understanding the failures, and 
to hinder the recurrent errors. Decreasing the frequency of adverse events is vital in the quality of care and safety (Hwang \& Park, 2017). The report “To Err Is Human” expresses that medical errors increase the mortality and morbidity rates of avoidable adverse events. They lead to deaths more than motor vehicle accidents, breast cancer and also AIDS (Kohn, Corrigan \& Donaldson, 2000). Nurses are among the fundamental healthcare providers and they may encounter with medical errors (Cho, Chin, Kim \& Hong, 2016; Kahriman \& Öztürk, 2016; Somyürek \& Uğur, 2016).

While patient safety culture is combined with minor medical errors, there has been restricted emprical research examining the perceptions of patient safety culture with medical error among nurses (Singer et al., 2009). The literature associated with patient safety culture concentrated on reducing medical errors and maintaining patient safety (Ammouri, Tailakh, Muliira, Geethakrishnan \& Al Kindi, 2014). Patient safety initiatives diminish medical error and provide quality care within the complexity of the health sector (Kalra \& Adams, 2016; Singer \& Vogus, 2013; Wolf \& Hughes, 2008). Health institutions are closely linked for errors or adverse events, and patient safety culture is considered to facilitate the labelling of speculative situations (Singla, Kitch, Weissman \& Campbell, 2006).

Unlike other goods and services, health services have low tolerance for errors and delays. In other words, an error in service delivery may lead to irreversible problems in health services. In essence, there should be zero error target in the field of health. However, the intense workload of the health sector, time pressure and constraints in health manpower in terms of quantity and quality cause errors. The searches continue to determine the factors for reducing medical errors in terms of organizations and employees. One of the factors that may be effective in reducing medical errors is the patient safety culture. It can be said that the number of studies examining these two variables together is limited in the literature. From the perspective of the health sector in Turkey, it has not been demonstrated in a study on this issue. With this aspect, it is believed that the study will contribute to the literature.

The aim of this study is to examine the effects of nurses' patient safety culture perceptions on their attitudes of medical errors. The following research hypotheses have been developed in accordance with the information provided by the literature.

Hypothesis 1. The perceptions of nurses in relation to the all dimensions of patient safety culture have a statistically significant effect on perception of medical error.

Hypothesis 2. The perceptions of nurses in relation to the all dimensions of patient safety culture have a statistically significant effect on approach of medical error. 
Hypothesis 3. The perceptions of nurses in relation to the all dimensions of patient safety culture have a statistically significant effect on causes of medical errors.

Hypothesis 4. The perceptions of nurses in relation to the all dimensions of patient safety culture have a statistically significant effect on all dimensions of medical error.

\section{METHODS}

This descriptive study was carried out to reveal the relationship between patient safety culture and medical errors. The research universe comprised 350 nurses working in a public hospital in the Antalya province. The convenience sampling method was used in the study. The data collection tool was distributed to all nurses who want to participate in the study. The data were obtained between October 2 and November 3, 2018, a total of 205 usable questionnaires were ensured.

The "Patient Safety Culture Hospital Questionnaire” was used to measure patient safety culture perceptions. The survey was developed by the Agency for Healthcare Research and Quality (AHRQ) in 2004 and adapted to Turkish by Filiz in 2009 (Filiz, 2009). It is composed of 42 items and 13 sub-dimensions (AHRQ, 2016). The items were rated on a 5-point Likert scale (“I never agree = 1”, “I don’t agree = 2”, “I am undecided =3”, “I agree =4”, "I totally agree $=5$ ”). The internal consistency coefficient (Cronbach's alpha) was 0.841 for this scale in this present study.

“The Scale of Attitudes towards Medical Errors”, developed by Güleç was used to measure attitudes of medical error in the study (Güleç, 2012). The scale composed of 16 items and 3 sub-dimensions (perception of medical error, approach of medical error and causes of medical error) and its items were rated on a 5-point Likert scale $(1=\mathrm{I}$ never agree, $5=\mathrm{I}$ totally agree). The internal consistency coefficient (Cronbach's alpha) was 0.843 for this scale in the present study.

The data were analyzed using SPSS software. Descriptive analysis, reliability analysis, and multivariate regression analysis were performed to reveal the relationship between patient safety culture and medical errors.

\section{Ethical approval}

This study was approved by Ethics Committee of Hacettepe University in accordance with its decision number 35853172/433-597. Informed consent form was handed out as hardcopy, attached by a covering letter informing potential participants of the research's aim and its voluntary nature. Thus, nurses were ensured to be volunteered to participate and the 
obtained data would be used entirely for academic purposes. Informed consent was collected from each participant involved in the research.

\section{RESULTS}

The descriptive features of participants are described in Table 1. It demonstrates that $48.8 \%$ of nurses were 34 years old or above; $89.3 \%$ of nurses were female, $58.0 \%$ had an undergraduate education. The table indicates that $51.7 \%$ of nurses have been working in the health sector for 10 years or more and half of the nurses (45.3\%) have been working in service unit.

Table 1.Descriptive Characteristics of Participants

\begin{tabular}{lcclcc}
\hline Variables & $\mathbf{N}$ & $\mathbf{\%}$ & Variables & $\mathbf{N}$ & $\mathbf{\%}$ \\
\hline Age(years) & & & Working Unit & & \\
\hline$\leq 33$ & 105 & 51.2 & Service & 93 & 45.3 \\
\hline$\geq 34$ & 100 & 48.8 & Outpatient clinic & 84 & 41.0 \\
\hline Gender & & & Emergency & 17 & 8.3 \\
\hline Female & 183 & 89.3 & Intensive care & 11 & 5.4 \\
\hline Male & 22 & 10.7 & $\begin{array}{l}\text { Duration of Working in the } \\
\text { Health Sector (years) }\end{array}$ & & \\
\hline Educational Level & & & $\leq 9$ & 99 & 48.3 \\
\hline High School & 14 & 6.8 & $\geq 10$ & 106 & 51.7 \\
\hline Associate & 56 & 27.3 & & & \\
\hline Undergraduate & 119 & 58.0 & & 205 & 100.0 \\
\hline Postgraduate & 16 & 7.9 & & & \\
\hline Total & 205 & 100.0 & Total & & \\
\hline
\end{tabular}

A regression analysis has been conducted to examine the hypotheses of research. The regression model for the effect of all sub-dimensions of patient safety culture on the medical error attitudes (perception of medical error, medical error approach and causes of medical error) have been presented in Table 2, 3, 4, and 5.

Table 2. The Effect of Patient Safety Culture Dimensions on The Perception of Medical Error

\begin{tabular}{|c|c|c|c|c|c|c|c|}
\hline \multirow{2}{*}{ Variables } & \multicolumn{2}{|c|}{$\begin{array}{l}\text { Unstandardized } \\
\text { Coefficients }\end{array}$} & \multirow{2}{*}{$\begin{array}{c}\text { Standardized } \\
\text { Coefficients } \\
\text { Beta }\end{array}$} & \multirow{2}{*}{$\mathrm{t}$} & \multirow{2}{*}{$p$} & \multirow{2}{*}{ Tolerance } & \multirow{2}{*}{ VIF } \\
\hline & B & $\begin{array}{c}\text { Std. } \\
\text { Error }\end{array}$ & & & & & \\
\hline Constant & 4.092 & .566 & & 7.231 & .000 & & \\
\hline General security perceptions & -.063 & .092 & -.049 & -.682 & .496 & .718 & 1.394 \\
\hline $\begin{array}{l}\text { Continuous improvement of } \\
\text { organizational learning }\end{array}$ & -.216 & .112 & -.193 & -1.925 & .056 & .373 & 2.681 \\
\hline Unit team study & -.065 & .095 & -.065 & -.681 & .496 & .411 & 2.435 \\
\hline Unrealized response for errors & -.054 & .065 & -.058 & -.823 & .412 & .745 & 1.342 \\
\hline Staff & -.035 & .088 & -.032 & -.397 & .692 & .582 & 1.720 \\
\hline $\begin{array}{l}\text { Executive's expectations/actions } \\
\text { for patient security }\end{array}$ & .294 & .116 & .194 & 2.540 & $.012 *$ & .644 & 1.552 \\
\hline Communication obviousness & .237 & .095 & .164 & 2.490 & $.014^{*}$ & .865 & 1.156 \\
\hline
\end{tabular}




\begin{tabular}{lccccccc}
\hline Feedback communication & -.228 & .083 & -.242 & -2.753 & $.006^{*}$ & .488 & 2.051 \\
regarding error & & & & & & & \\
Reported incident frequency & .073 & .054 & .100 & 1.349 & .179 & .681 & 1.469 \\
Teamwork between units & -.309 & .125 & -.170 & -2.473 & $.014^{*}$ & .798 & 1.254 \\
Equipment & .208 & .077 & .207 & 2.691 & $.008^{*}$ & .637 & 1.569 \\
Management support for patient & -.012 & .105 & -.008 & -.119 & .905 & .764 & 1.309 \\
safety & & & & & & & .934 \\
Number of reported events & -.103 & .066 & -.099 & -1.562 & .120 & .934 & 1.070 \\
\hline
\end{tabular}

Regression Summary

$\mathrm{R}=0.531 \quad \mathrm{R}^{2}=0.282 \quad \mathrm{~F}=5.772 \quad p=0.000 \quad$ Durbin Watson $=1.097$

$\mathrm{VIF}=$ Variance Inflation Factor, $\mathrm{R}^{2}=\mathrm{R}$ Square, *: Significant at $\mathrm{p}<0.05$

The regression model which demonstrate the effect of the patient safety culture on the perception of medical error has been presented in Table 2. The multiple regression models revealed a correlation coefficient of 0.531 , and patient safety culture dimensions explained $28.2 \%$ of the total variance in perception of medical error. The regression model was linear and statistically significant $(F=5.772, p<0.001)$. The investigation of the t-test results exhibited that participants' perceptions of their executive's expectations/actions for patient security ( $t=2.540, \quad p<0.05)$, communication obviousness $(t=2.490, \quad p<0.05)$, feedback communication $(t=-2.753, p<0.05)$, teamwork between units $(t=-2.473, p<0.05)$ and equipment $(t=2.691, p<0.05)$ statistically effect their perception of medical error. In accordance with the standardized regression coefficient $(\beta)$, the relative order of importance of the independent variables on perception of medical error were feedback communication (standardized $\beta=-0.242$ ), equipment (standardized $\beta=0.207$ ) and executive's expectations/actions for patient security (standardized $\beta=0.194$ ). This finding ensured the confirmation of Hypothesis 1.

Table 3. The Effect of Patient Safety Culture Dimensions on the Medical Error Approach

\begin{tabular}{|c|c|c|c|c|c|c|c|}
\hline \multirow{2}{*}{ Variables } & \multicolumn{2}{|c|}{$\begin{array}{l}\text { Unstandardized } \\
\text { Coefficients } \\
\end{array}$} & \multirow{2}{*}{$\begin{array}{c}\begin{array}{c}\text { Standardized } \\
\text { Coefficients }\end{array} \\
\text { Beta }\end{array}$} & \multirow{2}{*}{$\mathrm{t}$} & \multirow{2}{*}{$p$} & \multirow{2}{*}{ Tolerance } & \multirow[b]{2}{*}{ VIF } \\
\hline & B & $\begin{array}{l}\text { Std. } \\
\text { Error }\end{array}$ & & & & & \\
\hline Constant & 1.999 & .401 & & 4.985 & .000 & & \\
\hline General security perceptions & .025 & .065 & .028 & .382 & .703 & .718 & 1.394 \\
\hline $\begin{array}{l}\text { Continuous improvement of } \\
\text { organizational learning }\end{array}$ & .047 & .079 & .060 & .591 & .555 & .373 & 2.681 \\
\hline Unit team study & -.202 & .067 & -.292 & -3.010 & $.003 *$ & .411 & 2.435 \\
\hline Unrealized response for errors & .086 & .046 & .133 & 1.851 & .066 & .745 & 1.342 \\
\hline Staff & -.205 & .063 & -.267 & -3.279 & $.001 *$ & .582 & 1.720 \\
\hline $\begin{array}{l}\text { Executive's expectations/actions } \\
\text { for patient security }\end{array}$ & .118 & .082 & .111 & 1.440 & .151 & .644 & 1.552 \\
\hline Communication obviousness & .245 & .067 & .243 & 3.635 & $.000 *$ & .865 & 1.156 \\
\hline $\begin{array}{l}\text { Feedback communication } \\
\text { regarding error }\end{array}$ & -.009 & .059 & -.014 & -.158 & .875 & .488 & 2.051 \\
\hline Reported incident frequency & -.014 & .038 & -.028 & -.376 & .707 & .681 & 1.469 \\
\hline Teamwork between units & -.138 & .088 & -.108 & -1.557 & .121 & .798 & 1.254 \\
\hline Equipment & .099 & .055 & .140 & 2.805 & $.000 *$ & .637 & 1.569 \\
\hline
\end{tabular}




\begin{tabular}{|c|c|c|c|c|c|c|c|}
\hline $\begin{array}{l}\text { Management support for patien } \\
\text { Safety }\end{array}$ & .171 & .074 & .164 & 2.304 & .703 & .764 & 1.309 \\
\hline Number of reported events & -.034 & .047 & -.047 & -.734 & .555 & .934 & 1.070 \\
\hline $\begin{array}{l}\text { Regression Summary } \\
R=0.513 \quad R^{2}=0.264\end{array}$ & & $p=0.000$ & Durbin & $1=$ & & & \\
\hline
\end{tabular}

$\mathrm{VIF}=$ Variance Inflation Factor, $\mathrm{R}^{2}=\mathrm{R}$ Square, $*$ : Significant at $\mathrm{p}<0.05$

The effect of the patient safety culture on medical error approach has been tested with the regression model, and exhibited in Table 3. The results revealed a correlation coefficient of 0.513 , and patient safety culture dimensions explained $26.4 \%$ of the total variance in medical error approach. The regression model was linear and statistically significant $(F=5.261, p<0.001)$. The results revealed that participants' perceptions of their unit team study ( $t=-3.010, p<0.05)$, staff $(t=-3.279, p<0.05)$, communication obviousness $(t=3.635$, $p<0.05)$ and equipment $(t=2.805, \mathrm{p}<0.05)$ statistically effect their attitudes of medical error approach. The variable that most affected medical error approach was unit team study $(\beta=-$ 0.292). This finding ensured the confirmation of Hypothesis 2.

Table 4. The Effect of Patient Safety Culture Dimensions on the Causes of Medical Errors

\begin{tabular}{|c|c|c|c|c|c|c|c|}
\hline \multirow{2}{*}{ Variables } & \multicolumn{2}{|c|}{$\begin{array}{c}\text { Unstandardized } \\
\text { Coefficients }\end{array}$} & \multirow{2}{*}{$\begin{array}{c}\begin{array}{c}\text { Standardized } \\
\text { Coefficients }\end{array} \\
\text { Beta }\end{array}$} & \multirow{2}{*}{$\mathrm{t}$} & \multirow{2}{*}{$p$} & \multirow{2}{*}{ Tolerance } & \multirow[b]{2}{*}{ VIF } \\
\hline & B & $\begin{array}{l}\text { Std. } \\
\text { Error }\end{array}$ & & & & & \\
\hline Constant & 3.303 & .418 & & 7.896 & .000 & & \\
\hline General security perceptions & -.123 & .068 & -.136 & -1.807 & .072 & .718 & 1.394 \\
\hline $\begin{array}{l}\text { Continuous improvement of } \\
\text { organizational learning }\end{array}$ & .024 & .083 & .030 & .285 & .776 & .373 & 2.681 \\
\hline Unit team study & -.185 & .070 & -.263 & -2.635 & $.009 *$ & .411 & 2.435 \\
\hline Unrealized response for errors & .070 & .048 & .107 & 1.443 & .151 & .745 & 1.342 \\
\hline Staff & -.152 & .065 & -.195 & -2.329 & $.021 *$ & .582 & 1.720 \\
\hline $\begin{array}{l}\text { Executive's expectations/actions } \\
\text { for patient security }\end{array}$ & .122 & .086 & .113 & 1.424 & .156 & .644 & 1.552 \\
\hline Communication obviousness & .071 & .070 & .069 & 1.009 & .314 & .865 & 1.156 \\
\hline $\begin{array}{l}\text { Feedback communication } \\
\text { regarding error }\end{array}$ & -.072 & .061 & -.108 & -1.176 & .241 & .488 & 2.051 \\
\hline Reported incident frequency & -.004 & .040 & -.007 & -.088 & .930 & .681 & 1.469 \\
\hline Teamwork between units & -.125 & .092 & -.097 & -1.352 & .178 & .798 & 1.254 \\
\hline Equipment & .023 & .057 & .032 & .404 & .687 & .637 & 1.569 \\
\hline $\begin{array}{l}\text { Management support for patient } \\
\text { safety }\end{array}$ & .093 & .077 & .088 & 1.202 & .231 & .764 & 1.309 \\
\hline Number of reported events & .015 & .049 & .021 & .317 & .752 & .934 & 1.070 \\
\hline \multicolumn{8}{|l|}{ Regression Summary } \\
\hline
\end{tabular}

$\mathrm{VIF}=$ Variance Inflation Factor, $\mathrm{R}^{2}=\mathrm{R}$ Square, $*$ : Significant at $\mathrm{p}<0.05$

Table 4 presents the regression model for the effect of the patient safety culture on causes of medical errors. The model revealed a correlation coefficient of 0.467 and patient safety culture dimensions explained $21.8 \%$ of the total variance in causes of medical errors. The model was linear and statistically significant $(F=4.105, p<0.001)$. The results showed that 
participants' perceptions of their unit team study $(t=-2.635, p<0.05)$ and staff $(t=-2.329$, $p<0.05)$ statistically effect causes of medical errors. The variable that most affected the causes of medical error was unit team study $(\beta=-0.263)$. This finding ensured the confirmation of Hypothesis 3.

The regression model for the effect of the patient safety culture on all subdimensions of medical errors has been presented in Table 5. The model revealed a correlation coefficient of 0.566 and patient safety culture dimensions explained $32.0 \%$ of the total variance in all subdimensions of medical error. The model was linear and statistically significant $(F=6.913$, $p<0.001)$. The model revealed that participants' perceptions of their unit team study ( $t=-3.349$, $p<0.05)$, staff $(t=-2.831, p<0.05)$, communication obviousness $(t=2.955, p<0.05)$ and teamwork between units $(t=-2.029, p<0.05)$ statistically effect all subdimensions of medical error. According to the standardized regression coefficient $(\beta)$, unit team study was the variable that most affected medical errors $(\beta=-0.312)$. This finding ensured the confirmation of Hypothesis 4.

Table 5. The Effect of Patient Safety Culture Subdimensions on All Subdimensions of the Medical Errors

\begin{tabular}{|c|c|c|c|c|c|c|c|}
\hline \multirow{2}{*}{ Variables } & \multicolumn{2}{|c|}{$\begin{array}{l}\text { Unstandardized } \\
\text { Coefficients }\end{array}$} & \multirow{2}{*}{$\begin{array}{c}\text { Standardized } \\
\text { Coefficients } \\
\text { Beta }\end{array}$} & \multirow{2}{*}{$\mathrm{t}$} & \multirow{2}{*}{$p$} & \multirow{2}{*}{ Tolerance } & \multirow[b]{2}{*}{ VIF } \\
\hline & B & $\begin{array}{l}\text { Std. } \\
\text { Error }\end{array}$ & & & & & \\
\hline Constant & 2.947 & .326 & & 9.028 & .000 & & \\
\hline General security perceptions & -.055 & .053 & -.073 & -1.038 & .300 & .718 & 1.394 \\
\hline $\begin{array}{l}\text { Continuous improvement of } \\
\text { organizational learning }\end{array}$ & .027 & .065 & .040 & .412 & .681 & .373 & 2.681 \\
\hline Unit team study & -.183 & .055 & -.312 & -3.349 & $.001 *$ & .411 & 2.435 \\
\hline Unrealized response for errors & .068 & .038 & .125 & 1.803 & .073 & .745 & 1.342 \\
\hline Staff & -.144 & .051 & -.222 & -2.831 & $.005^{*}$ & .582 & 1.720 \\
\hline $\begin{array}{l}\text { Executive's expectations/actions } \\
\text { for patient security }\end{array}$ & .112 & .067 & .125 & 1.681 & .094 & .644 & 1.552 \\
\hline Communication obviousness & .162 & .055 & .190 & 2.955 & $.004^{*}$ & .865 & 1.156 \\
\hline $\begin{array}{l}\text { Feedback communication } \\
\text { regarding error }\end{array}$ & -.066 & .048 & -.119 & -1.389 & .166 & .488 & 2.051 \\
\hline Reported incident frequency & -.013 & .031 & -.031 & -.422 & .673 & .681 & 1.469 \\
\hline Teamwork between units & -.146 & .072 & -.136 & -2.029 & $.044 *$ & .798 & 1.254 \\
\hline Equipment & .076 & .045 & .127 & 1.698 & .091 & .637 & 1.569 \\
\hline $\begin{array}{l}\text { Management support for patient } \\
\text { safety }\end{array}$ & .093 & .060 & .105 & 1.532 & .127 & .764 & 1.309 \\
\hline Number of reported events & -.022 & .038 & -.035 & -.575 & .566 & .934 & 1.070 \\
\hline \multicolumn{8}{|l|}{ Regression Summary } \\
\hline
\end{tabular}




\section{DISCUSSION}

Patient safety culture is a very important tool, and several initiatives have been performed to improve patient safety culture in health care organizations in Turkey. Many health care service providers are involved in the provision of health services and maintaning safe patient care. Nurses have prominent responsibility in assuring patient safety and diminishing medical errors (Aboshaiqah, 2010; Top \& Tekingündüz, 2015). As they communicate directly with patients in health care provision, they are in charge of informing patients about risks, initiating and maintaning patient safety culture and reporting medical errors (Çırpı, Doğan Merih \& Yaşar Kocabey, 2009).This study investigates the effects of patient safety culture perceptions on their attitudes of medical errors among nurses. Although many studies have implied that safety culture is relevant with fewer medical errors, this study indicates empirical research findings linking the perceptions of patient safety culture with medical error among nurses.

This study demonstrated that patient safety culture dimensions explained $28.2 \%$ of the total variance in perception of medical error. The results showed that participants' perceptions of their executive's expectations/actions for patient security, communication obviousness, feedback communication, teamwork between units and equipment statistically affected their perception of medical error. The findings of another study in Turkey demonstrate that health employees consider that the patient safety culture is not at a good level and the development of safety culture is needed in health institutions. In addition, health employees face with a punitive approach in case of medical errors in their institutions. The management does not support themselves with regards to patient safety culture (Filiz, 2009). However administration endorsement is essential in the development of patient safety culture in health institutions. A patient safety culture is chiefly developed by group work, management endorsement, conformity with rules, training, engagement of employees, and improvement of the secure health care system (Hughes \& Clancy, 2009).

Another result revealed that patient safety culture dimensions explained $26.4 \%$ of the total variance in medical error approach. In the regression model, it was determined that participants' perceptions of their unit team study, staff, communication obviousness and equipment statistically affected their attitudes of medical error approach. The variable that most affected the medical error approach was unit team study. From this point of view, as the patient safety culture is improved in nursing, medical errors may be openly discussed with the nurses and all errors may be reported. 
Another regression demonstrated that patient safety culture dimensions explained $21.8 \%$ of the total variance in causes of medical errors. In the regression model, it was found that participants' perceptions of their unit team study and staff statistically affected the causes of medical errors. The variable that most affected the causes of medical error was unit team study. Medical errors may cause to duplicate tests, procedures and procedures, increase the duration of the day of stay in the hospital, raise health expenditures and create new disabilities and complications (Farquhar Sharp, \& Clancy, 2007; Pronovost, Thompson, Holzmueller, Lubomski \& Morlock, 2005; Slonim, LaFleur, Wendy \& Joseph, 2003; Zhan \& Miller, 2003). Thus, the determination of causes of medical errors is considered as important. There are various causes of medical error such as communication in efficacy, system failures, lack of information of the person making the error, excessive number of patients given care, long working hours, actually preventable medical errors, etc. If the patient safety culture is constituted in nursing, it may facilitate the determination of the causes of medical errors. For this reason, the efforts to develop patient safety culture should be over emphasized.

The results of the fourth regression analysis show that patient safety culture dimensions explained $32.0 \%$ of total variance in all subdimensions of medical error. The study revealed that participants' perceptions of their unit team study, staff, communication obviousness and teamwork between units statistically effect all subdimensions of medical error. The variable that most affected the total variance of medical error was unit team study. It can be emphasized that unit team study is important in reducing medical errors. Mardon et al. found that hospitals with higher patient safety culture scores had lower rates of in-hospital complications or adverse events after controlling for hospital bed size, teaching status, and ownership (Mardon, Khanna, Sorra, Dyer \& Famolaro, 2010). In another study, the patient safety culture and its relationship with patient safety indicators on health care employees was examined. It was found that better safety climate caused minor incident reports (Weingart, Farbstein, Davis \& Phillips, 2004). Singer and Vogus suggested that enacting safety culture reduced medical errors. Errors stand out intervention since too many interventions may cause the basic source of errors: weak organizational safety culture (Singer \& Vogus, 2013). Kagan and Barnoy found that most nurses experienced medical errors from a daily to a weekly basis (Kagan \& Barnoy, 2013). They found that positive relations were found between the level of patient safety culture and the error-reporting rate. In other words, patient safety culture scores are connected with a lower medical error incidence rate (as reported by nurses). It was determined that positive and cautiously projected safety culture could inspire error reporting by employees and develop patient safety (Kagan \& Barnoy, 2013). 


\section{CONCLUSION}

This study is important in terms of demonstrating the empirical link between perceptions of patient safety culture and medical error among nurses. The study findings suggest that managers in health institutions should show an approach that supports learning from mistakes, made by nurses. Thus, nurses may connect patient safety culture and patient outcomes. A corporate culture created in this way allows nurses to be the leaders ensuring that the patients are safe. This study provides insight about developing systems that will facilitate reporting of medical problems related to patient safety in health institutions, facilitating discussions and taking lessons from mistakes. The creation of a non-punitive reporting system is recommended. Legal arrangements should be ensured that health employees report medical errors.

The results of this study have limitations because they cannot be generalized to all nurses. The sample of this study consists of nurses working in public hospitals in one Turkish province. Future studies may be designed with broader samples and longitudinally. Thus, it may produce more comprehensive results to clarify the causal relationships between the variables. Following researches should be conducted using cross sectional analysis and other variables that demonstrate the connection between patient safety culture and patient consequences.

\section{REFERENCES}

Aboneh, E. A., Stone, J. A., Lester, C. A., Chui, M. A. (2020). Evaluation of patient safety culture in community pharmacies. Journal of Patient Safety. 16(1), e18-e24.

Aboshaiqah, A. E. (2010). Patients safety culture: a baseline assessment of nurses' perceptions in a Saudi Arabia hospital. Unpublished doctoral dissertation, Wayne State University, Detroit.

AHRQ (2016). Hospital survey on patient safety culture. 05 May 2020, https://www.ahrq.gov/sites/default/files/wysiwyg/professionals/quality-patientsafety/patientsafetyculture/ hospital/userguide/hospcult.pdf

Ammouri, A. A., Tailakh, A. K., Muliira, J. K., Geethakrishnan, R., Al Kindi, S. N. (2014). Patient safety culture among nurses. International Nursing Review, 62(1), 102-110.

Cho, E., Chin, D. L., Kim, S., Hong, O. (2016). The relationships of nurse staffing level and work environment with patient adverse events. Journal of Nursing Scholarship, 48(1), 74-82.

Çırpı, F., Doğan Merih, Y., Yaşar Kocabey, M. (2009). Nursing practices that are aims to patient safe and determining the nurses point view of this topic. Maltepe Univ E-J Nurs Sci Art, 3(2), $26-34$.

Dikmen, Y. D., Yorgun, S., Yeşilçam, N. (2014). Identification the level of tendency in malpractice among nurses. Journal of Hacettepe University Faculty of Nursing, 44-56. 
Elsous, A., Sari, A. A., Rashidian, A., Aljeesh, Y., Radwan, M., AbuZaydeh, H. A. (2016). Cross-sectional study to assess the patient safety culture in the Palestinian hospitals: A baseline assessment for quality improvement. Journal of the Royal Society of Medicine Open, 7(12), 1-12.

Farquhar, M., Sharp, B. A., Clancy, C. M. (2007). Patient safety in nursing practice. AORN Journal, 86(3), 4557.

Filiz, E. (2009). Determination of perception of patient safety culture in hospitals and of health staff and patient attitudes about patient safety. Unpublished Master Thesis, Selçuk University, Konya.

Güleç, D. (2012). Development of the medical errors attitude scale. Unpublished Master Thesis, Dokuz Eylül University, İzmir.

Handler, S. M., Castle, N. G., Studenski, S. A., Perera, S., Fridsma, D. B., Nace, D. A., Hanlon, J. T. (2006). Patient safety culture assessment in the nursing home. Quality \& Safety in Health Care, 15(6), 400-404.

Hughes, R. G., Clancy, C. M. (2009). Nurses's role in patient safety. Journal of Nursing Care Quality, 24(1), 14.

Hwang, J. I., Park, H. A. (2017). Nurses' systems thinking competency, medical error reporting, and the occurrence of adverse events: a cross-sectional study. Contemporary Nurse, 53(6), 622-632.

Institute of Medicine (2004). Patient Safety: Achieving A New Standard of Care. Washington, DC: The National Academies Press.

Iramaneerat, C., Noppakunsomboon, N. (2016). The patient safety attitudes among the operating room personnel. Siriraj Medical Journal, 68(4), 203-208.

Kagan, I., Barnoy, S. (2013). Organizational safety culture and medical error reporting by Israeli nurses. Journal of Nursing Scholarship, 45(3), 273-280.

Kahriman, I., Öztürk, H. (2016). Evaluating medical errors made by nurses during their diagnosis, treatment and care practices. Journal of Clinical Nursing, 25(19-20), 2884-94.

Kalra, J., Adams, S. J. (2016). Medical error and patient safety: Fostering a patient safety culture. Austin Journal of Clinical Pathology, 3(1), 1041-1043.

Karatass, M., Yakinci, C. (2010). Causes of medical errors and solutions. Journal of Inonu University Medical Faculty, 17(3), 233-236.

Kohn, L. T., Corrigan, J. M., Donaldson, M. S. (2000). Errors in healthcare: A leading cause of dealth and injury. In: Kohn, L. T., Corrigan, J. M., Donaldson, M. S. (Eds.). To err is human: Building a safer health system. Washington, DC: Institute of Medicine National Academy Press.

Mardon, R. E., Khanna, K., Sorra, J., Dyer, N., Famolaro, T. (2010). Exploring relationships between hospital patient safety culture and adverse events. Journal of Patient Safety, 6(4), 226-232.

Nieva, V. F., Sorra, J. (2003). Safety culture assessment: a tool for improving patient safety in healthcare organizations. Qual Saf Health Care, 12 (Suppl 2), 17-23.

Pronovost, P. J., Thompson, D. A., Holzmueller, C. G., Lubomski, L. H., Morlock, L. L. (2005). Defining and measuring patient safety. Critical Care Clinics, 21(2), 1-19.

Sammer, C. E., Lykens, K., Singh, K. P., Mains, D. A., Lackan, N. A. (2010). What is patient safety culture? A review of the literature. Journal of Nursing Scholarship, 42(2), 156-165.

Singer, S., Lin, S., Falwell, A., Gaba, D., Baker, L. (2009). Relationship of safety cimate and safety performance in hospitals. Health Services Research, 44(2), 399-421. 
Singer, S. J., Vogus, T. J. (2013). Reducing hospital errors: interventions that build safety culture. Annual Review of Public Health. 34, 373-396.

Singla, A. K., Kitch, B. T., Weissman, J. S., Campbell, E. G. (2006). Assessing patient safety culture: A review and synthesis of the measurement tools. Journal of Patient Safety, 2(3), 105-115.

Slonim, A. D., LaFleur, B. J., Wendy, A., Joseph, J. G. (2003). Hospital-reported medical errors in children. Offical Journal of the American Academy of Pediatrics, 111(3), 617-621.

Somyürek, N., Uğur, E. (2016). Creation of a patient safety culture in intensive care units: nurses' view to the medical errors. Journal of Health and Nursing Management, 3(1), 1-7.

Stavrianopoulos, T. (2012). The development of patient safety culture. Health Science Journal, 6(2), $201-211$.

Top, M., Tekingündüz, S. (2015). Patient safety culture in a Turkish public hospital: A study of nurses' perceptions about patient safety. Systemic Practice Action Research, 28(2), 87-110.

Tschudi Bondevik, G., Hofoss, D., Sandgathe, B., Husebø, B. S., Hofoss, D., Deilkås, E. C. T. (2017). Patient safety culture in Norwegian nursing homes. BMC Health Services Research, 17(1), 424-434.

Wagner, L. M., Brush, B. L., Castle, N. G., Engberg, J. B., Capezuti, E. A. (2017). Nursing home patient safety culture perceptions among US and immigrant nurses. Journal of Patient Safety, 1549-8417.

Weingart, S. N., Farbstein, K., Davis, R. B., Phillips, R. S. (2004). Using a multihospital survey to examine the safety culture.The Joint Commission Journal on Quality and Safety, 30(3), 125-32.

Wolf, Z. R., Hughes, R. G. (2008). Error reporting and disclosure. In: Patient safety and quality: An evidencebased handbook for nurses. Hughes RG (Ed.). Rockville (MD): Agency for Healthcare Research and Quality.

Zhan, C., Miller, M. R. (2003). Excess length of stay, charges, and mortality attributable to medical injuries during hospitalization. JAMA. 290(14), 1868-74. 